\title{
Synaptic Modulation by Dopamine of Calcium Currents in Rat Pars Intermedia
}

\author{
Peter J. Williams, Brian A. MacVicar, and Quentin J. Pittman \\ Neuroscience Research Group, University of Calgary, Calgary, Alberta, Canada T2N 4N1
}

Melanotrophs of the rat pars intermedia are innervated by dopaminergic fibers traveling through the pituitary stalk which inhibit secretion via an action on D-2 receptors. As secretion from the melanotroph has been shown to be calcium $\left(\mathrm{Ca}^{2+}\right)$ dependent, it is possible that dopamine may have an action to inhibit $\mathrm{Ca}^{2+}$ currents in these cells. This possibility was tested by examining the effects of exogenously applied dopaminergic agonists or synaptically released dopamine upon $\mathrm{Ca}^{2+}$ currents recorded under single electrode voltage clamp in intact rat pars intermedia in vitro.

Following blockade of sodium and potassium currents in melanotrophs, $\mathrm{Ca}^{2+}$ spikes were elicited with intracellular injection of depolarizing currents; electrical stimulation of the pituitary stalk caused an inhibition of the $\mathrm{Ca}^{2+}$-based action potentials which lasted for several seconds. Using single-electrode voltage-clamp techniques, we recorded inward $\mathrm{Ca}^{2+}$ currents corresponding to the $\mathrm{T}, \mathrm{N}$, and $\mathrm{L}$ types (see Williams et al., 1990). Stimulation of the pituitary stalk inhibited both the low- and high-threshold peak inward $\mathrm{Ca}^{2+}$ currents elicited from a holding potential of $-90 \mathrm{mV}$. In contrast, when noninactivating $\mathrm{Ca}^{2+}$ currents were elicited from a holding potential of $-30 \mathrm{mV}$, the currents were not altered by stalk stimulation. This pattern of inhibition of the $\mathrm{Ca}^{2+}$ currents was consistent with the preferential inhibition, by stalk stimulation, of the $\mathrm{N}$ and $\mathrm{T} \mathrm{Ca}^{2+}$ currents, while sparing the $L$ current.

We observed that inhibition of $\mathrm{Ca}^{2+}$ currents due to stalk stimulation was completely reversed by bath perfusion of domperidone $(1 \mu \mathrm{M})$, an antagonist of dopamine at the D-2 receptor. Quinpirole, a D-2 receptor agonist, mimicked the action of pituitary stalk stimulation by inhibiting $\mathrm{Ca}^{2+}$ currents elicited from a holding potential of $-90 \mathrm{mV}$, but not from $-30 \mathrm{mV}$.

To examine the role of G-proteins in mediating dopaminergic inhibition of $\mathrm{Ca}^{2+}$ currents in the melanotrophs, rats were pretreated with pertussis toxin, which blocks the actions of some G-proteins. In pertussis toxin-treated rats, only $25 \%$ of cells showed any inhibition of $\mathrm{Ca}^{2+}$ currents due to stalk stimulation compared with $100 \%$ of controls. In another

\footnotetext{
Received May 18, 1989; revised Aug. 24, 1989; accepted Sept. 27, 1989.

This work was supported by Medical Research Council of Canada. P.J.W. is an Alberta Heritage Foundation for Medical Research student; B.A.M. and Q.J.P. are AHFMR Scholars and MRC Scientists. Thanks to Laurel Franklin and Stephanie Crichton for technical assistance.

Correspondence should be addressed to Peter J. Williams, Medical Physiology, University of Calgary, 3330 Hospital Dr. NW, Calgary, Alberta, Canada T2N $4 \mathrm{~N} 1$.

Copyright (C) 1990 Society for Neuroscience $0270-6474 / 90 / 030757-07 \$ 02.00 / 0$
}

series of experiments, cells were impaled with electrodes containing GTP $\gamma \mathbf{S}$, a GTP analog which leads to irreversible activation of G-proteins. In these cells, only the noninactivating $\mathrm{Ca}^{2+}$ current was present, indicating that the transient currents normally inhibited by dopamine were already maximally inhibited by GTP $\gamma$ S.

These experiments thus indicate that both exogenously applied D-2 agonist and synaptically released dopamine act at a D-2 receptor on the melanotroph to inhibit certain $\mathrm{Ca}^{2+}$ currents via a G-protein mediated mechanism. This is the first characterization of synaptic modulation, by dopamine, of $\mathrm{Ca}^{2+}$ currents in the mammalian nervous system.

The melanotroph of the pars intermedia is a neuroendocrine cell which synthesizes and releases $\alpha$-melanocyte-stimulating hormone $(\alpha \mathrm{MSH})$ and several peptides of the endorphin family (Goldman et al., 1983). These cells show many of the ionic currents typical of neurons; in particular, they generate action potentials comprising both sodium $\left(\mathrm{Na}^{+}\right)$and calcium $\left(\mathrm{Ca}^{2+}\right)$ components (Douglas and Taraskevich, 1980). $\mathrm{Ca}^{2+}$ is required for secretion from these cells (Taraskevich et al., 1986).

Melanotrophs are known to be under inhibitory control mediated via dopaminergic fibers which arise in the hypothalamus, travel through the pituitary stalk, and synapse directly on the melanotrophs (Baumgarten et al., 1972; Howe, 1973). Dopamine (DA) appears to act on a population of D-2 receptors on the melanotroph, which, when activated, reduce action potential frequency (Douglas and Taraskevich, 1978, 1982) and depress hormone release (Tilders et al., 1975; Cote et al., 1985). We have described an action of synaptically released DA at this synapse which hyperpolarizes the cell through an increase in potassium $\left(\mathrm{K}^{+}\right)$conductance (Williams et al., 1989a). As it is now well established that a number of inhibitory transmitters, including DA, can inhibit voltage-sensitive $\mathrm{Ca}^{2+}$ channels (reviewed by Miller, 1987; Tsien et al., 1988), we hypothesize that DA may have an additional action at the melanotroph to inhibit $\mathrm{Ca}^{2+}$ currents. We (Williams et al., 1990) and others (Taleb et al., 1986) have previously described 3 different $\mathrm{Ca}^{2+}$ currents in the melanotroph which appear to correspond to the $T, N$, and $L$ types described in a number of other neuronal types (Nowycky et al., 1985; McCleskey et al., 1986). In the present experiments, we have carried out single-electrode voltage-clamp recordings in melanotrophs under conditions allowing the isolation and measurement of $\mathrm{Ca}^{2+}$ currents in order to identify the action of synaptically released DA and exogenously applied DA agonists on these currents. We have also investigated the participation of $\mathrm{G}$-proteins in the modulation of $\mathrm{Ca}^{2+}$ currents in the melanotroph. 
Figure 1. $A$, Stalk stimulation inhibits calcium spikes. $\mathrm{Ca}^{2+}$ spikes (upper) in response to intracellular injection of depolarizing current (lower) in a melanotroph in the intact isolated pituitary. Calcium-based action potentials are shown before (1), approximately $2 \mathrm{sec}$ after (2) and following recovery (3) from stimulation of the pituitary stalk (10 pulses at $50 \mathrm{~Hz}$ ). $B$, A slower time trace of the experiment described in $A$ indicating the points from which the voltage traces were taken and the time at which the stalk $(S)$ was stimulated from a bipolar electrode positioned on the stalk. This experiment and all subsequent experiments from which the figures in this paper were obtained were carried out in the presence of $100 \mu \mathrm{M}$ bicuculline and $0.5 \mathrm{~mm} 4-\mathrm{AP}$ in the perfusate. The intracellular electrode contained QX-222 to block $\mathrm{Na}^{+}$spikes and TEA and $\mathrm{Cs}^{+}$acetate to block $\mathrm{K}^{+}$conductances.

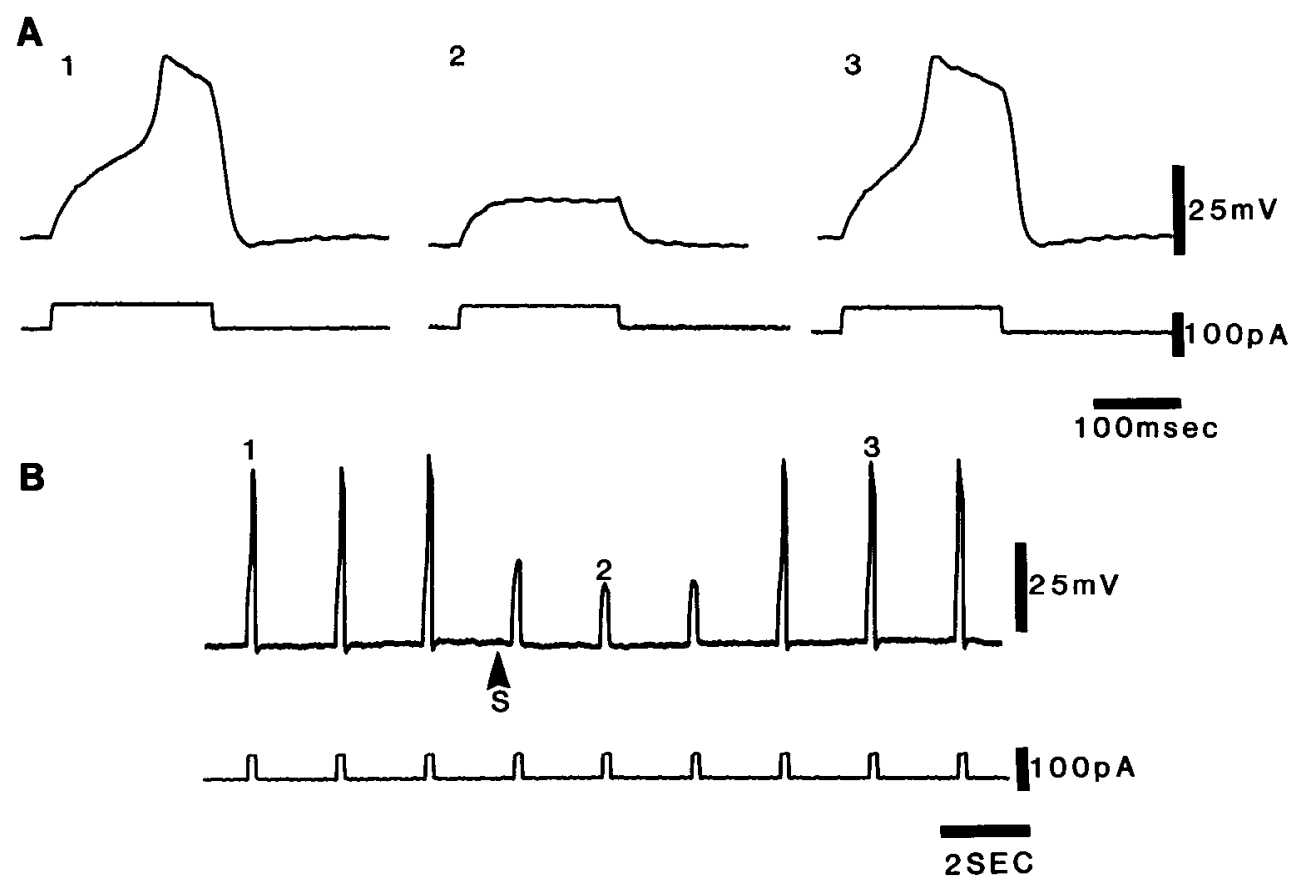

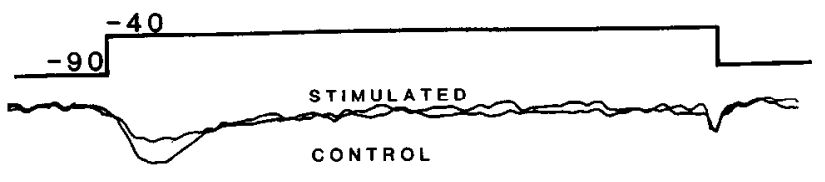
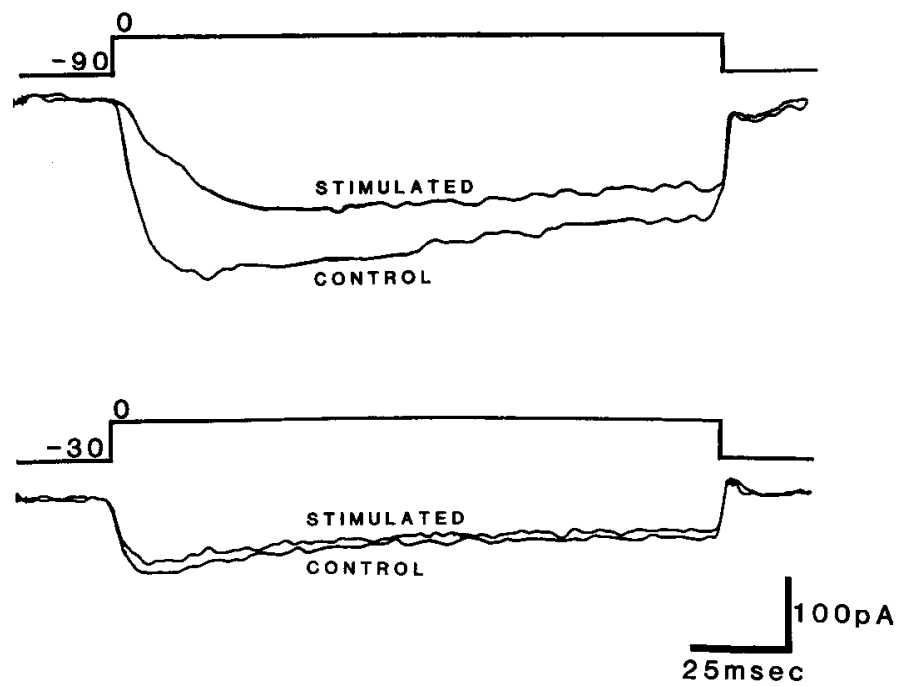

Figure 2. Stalk stimulation inhibits calcium currents evoked from a $-90 \mathrm{mV}$ holding potential, but not from $-30 \mathrm{mV}$. Voltage-clamp current recordings from a melanotroph, wherein the voltage was clamped to the holding potentials indicated to the left of each voltage trace and then stepped up to the membrane potentials indicated above each voltage trace. Current traces are indicated below each voltage trace and are taken before (Control) and after (Stimulated) stimulation of the pituitary stalk $(10 \mathrm{~V}, 1 \mathrm{msec}$, single pulse). Cobalt-insensitive leak currents have been subtracted from this and all subsequent figures.

\section{Materials and Methods}

Experimental procedures for maintenance of pituitaries in vitro, as well as isolation and measurement of $\mathrm{Ca}^{2+}$ currents, were identical to those described in the preceding paper (Williams et al., 1990). Of particular relevance to the present experiments is the fact that $\mathrm{Na}$ currents are inhibited by intracellular injection of a $\mathrm{Na}^{+}$channel blocker, QX-222, thus avoiding the need to add TTX to the perfusion fluid and allowing us to stimulate afferents to the melanotrophs. $\mathrm{Ca}^{2+}$ currents and spikes were isolated by impaling cells with microelectrodes (80-100 M $\Omega$ ) containing QX-222 (1 mM), cesium $\left(\mathrm{Cs}^{+}\right)$acetate $(0.5 \mathrm{M})$, and TEA acetate $(50 \mathrm{mM})$ to block $\mathrm{Na}^{+}$and $\mathrm{K}^{+}$currents. The extracellular medium contained 4-aminopyridine (4-AP) to ensure complete block of melanotroph $\mathrm{K}^{+}$currents. Afferent stimulation was accomplished with a bipolar silver stimulating electrode positioned on the cut end of the pituitary stalk approximately $3 \mathrm{~mm}$ from the recording site in the intermediate lobe. All experiments were carried out in the presence of $100 \mu \mathrm{M} \mathrm{bi-}$ cuculline to block a GABA $\wedge_{\wedge}$-mediated chloride conductance which can also be activated following stalk stimulation (MacVicar and Pittman, 1986; Williams et al., 1989b). Using a multiple-valve system, D-2 agonists or antagonists of known concentrations were introduced into the recording chamber without disrupting the flow of perfusate. To evaluate the potential role of $G$-proteins, rats were pretreated with pertussis toxin as previously described (Aghajanian and Wang, 1986; Colmers and Pittman, 1989). Briefly, rats were anesthetized with sodium pentobarbital and, under stereotaxic control, given an injection of $1.5 \mu \mathrm{g}$ pertussis toxin in $15 \mu \mathrm{l}$ artificial cerebrospinal fluid into a lateral cerebral ventricle (Pittman et al., 1985). They were allowed to recover for 3-4 d hefore pituitaries were taken for electrophysiological studies.

Bicuculline methiodide, 4-AP, and tetraethylammonium chloride (TEA) were obtained from Sigma (St. Louis); all other salts were obtained from Fisher Scientific (Fair Lawn, NJ). Pertussis toxin was purchased from List Laboratories, and GTP $\gamma$ S from Boehringer-Mannheim. Domperidone, quinpirole, and QX-222 were respective gifts of Janssen Pharmaceuticals, Eli Lilly Laboratories, and Astra Pharmaceuticals. Drugs were stored as stock solutions and protected from light until they were dissolved in the perfusate immediately before use.

\section{Results}

Intracellular recordings were obtained from melanotrophs that displayed resting potentials of $-40 \mathrm{mV}$ or more and input resistances of $>400 \mathrm{M} \Omega$. Action potentials could be elicited in all 


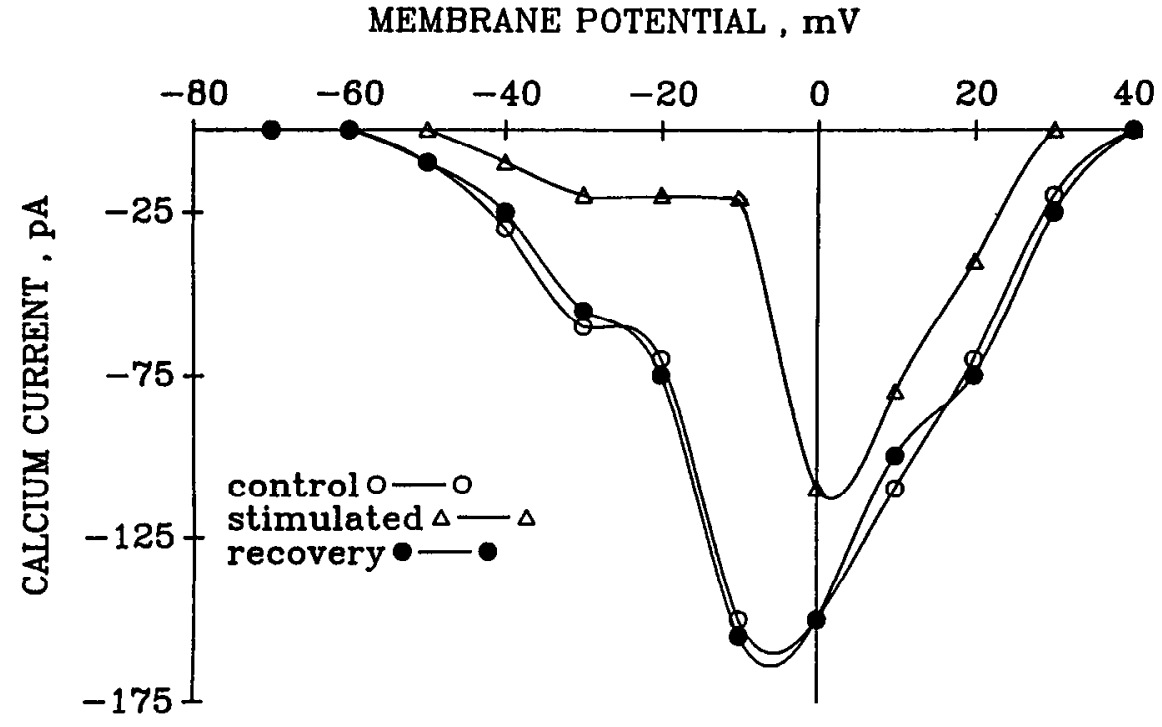

Figure 3. Stalk stimulation reversibly reduces inward calcium currents evoked from $-90 \mathrm{mV}$ holding potential. Current voltage traces from a typical experiment show $\mathrm{Ca}^{2+}$ currents $(\mathrm{pA})$ before (open circles) and after stimulation of the pituitary stalk (open triangles) and following recovery (closed circles). In these experiments, holding potential was at $-90 \mathrm{mV}$, and voltage was stepped in $10 \mathrm{mV}$ increments to the levels indicated by the data points. Voltage steps were elicited at 3-5 sec intervals to prevent possible time-dependent inactivation of the currents. cells and a proportion of them displayed spontaneous activity. When cells were impaled with electrodes to isolate $\mathrm{Ca}^{2+}$ responses as described above, $\mathrm{Ca}^{2+}$ spikes could be elicited by intracellular injection of depolarizing current. When these $\mathrm{Ca}^{2+}$ based action potentials were elicited at $2 \mathrm{sec}$ intervals, stimulation of the pituitary stalk $(5-10 \mathrm{~V}, 1 \mathrm{msec}$ duration, $1-10$ pulses at $50 \mathrm{~Hz}$ ) abolished the $\mathrm{Ca}^{2+}$ spike for periods of several seconds ( $n=6$, Fig. 1). Intracellular injection of hyperpolarizing current pulses indicated that there was no change of membrane input resistance at a time when the $\mathrm{Ca}^{2+}$ spikes were depressed. The absence of a hyperpolarization or a change in input resistance in response to stalk stimulation confirms that the combination of pharmacological blockers used has abolished the $\mathrm{DA}$-activated $\mathrm{K}^{+}$conductance known to be present in the melanotroph (Williams et al., 1989a). Only $\mathrm{Ca}^{2+}$ spikes elicited with current pulses slightly suprathreshold were abolished by stalk
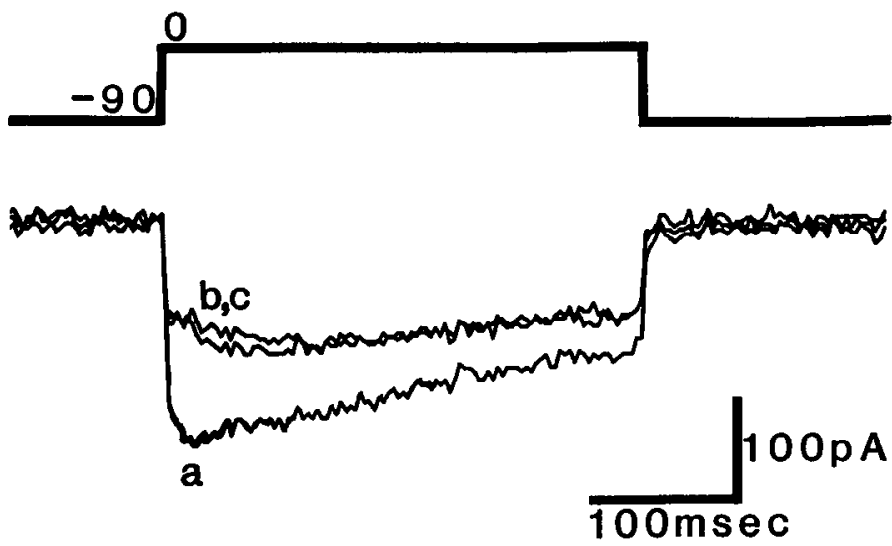

Figure 4. Stalk stimulation abolishes a transient $\mathrm{Ca}^{2+}$ current. The $\mathrm{Ca}^{2+}$ current elicited by a $400 \mathrm{msec}$ voltage pulse from a holding potential of $-90 \mathrm{mV}$ to a test potential of $0 \mathrm{mV}(a)$ had an inactivating $\mathrm{N}$ component. When the same pulse was elicited $150 \mathrm{msec}$ after a prepulse ( $200 \mathrm{msec}$ duration) to a potential of $+10 \mathrm{mV}$ the initial, more rapidly decaying current was abolished while a sustained, nondecaying current persisted $(b)$. A similar response was observed when the test pulse was preceded by a stimulus to the pituitary stalk $(c)$. A single pulse to the stalk $(10 \mathrm{~V}, 1 \mathrm{msec})$ abolished the same transient current that was eliminated by the prepulse. stimulation. $\mathrm{Ca}^{2+}$ spikes evoked with voltage pulses much greater than threshold for the spike were usually not abolished; rather, the duration of the spike was reversibly decreased $(n=3)$. To more rigorously characterize this effect, single-electrode voltageclamp technique was used to analyze the $\mathrm{Ca}^{2+}$ currents. In all cases, these currents were subsequently shown to be blocked by perfusion of cobalt or cadmium, and values reported for $\mathrm{Ca}^{2+}$ currents have been subtracted for the leak currents obtained in the presence of cobalt. $\mathrm{Ca}^{2+}$ currents corresponding to the $\mathrm{T}, \mathrm{N}$, and $L$ types (Nowycky et al., 1985) and previously described by us (Williams et al., 1990) were obtained (Fig. 2). When the holding potential was $-90 \mathrm{mV}$, stimulation of the pituitary stalk inhibited both the low- and the high-threshold peak inward $\mathrm{Ca}^{2+}$ current. Currents elicited by $200 \mathrm{msec}$ pulses from -90 to 0 a

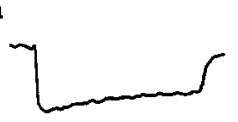

b
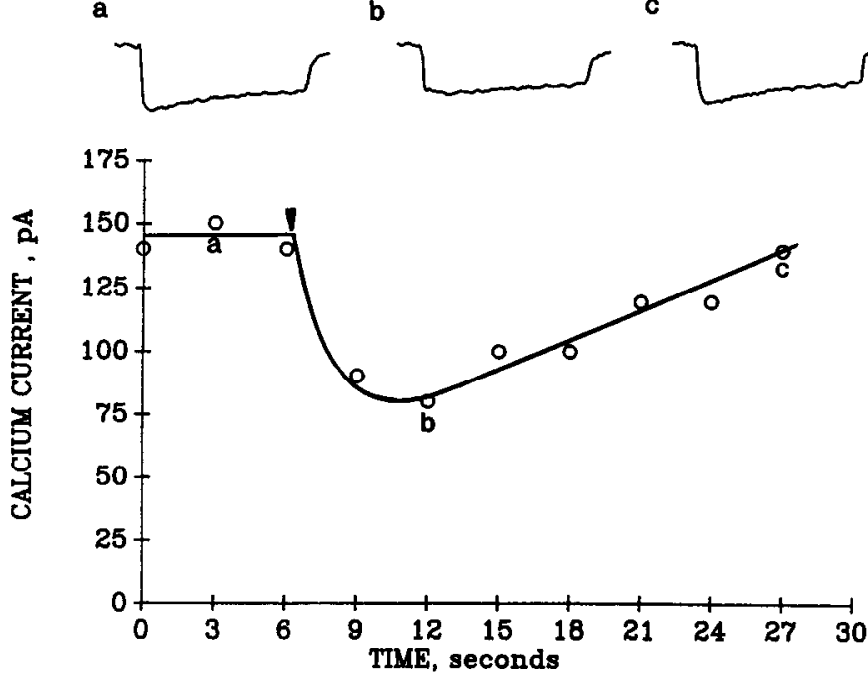

Figure 5. Duration of depressant action of stalk stimulation on $\mathrm{Ca}^{2+}$ currents. Top, Calcium currents elicited in response to $200 \mathrm{msec}$ voltage steps to $0 \mathrm{mV}$ from a holding potential of $-90 \mathrm{mV}$ before $(a)$, and 6 $\sec (b)$ and $22 \sec (c)$ after stimulation of the pituitary stalk. Lower, Peak $\mathrm{Ca}^{2+}$ currents and the time course of their reduction following stimulation of the pituitary stalk ( 1 pulse, $10 \mathrm{~V}, 1 \mathrm{msec})$ at the time indicated by the arrow. The letters $a-c$ indicate the points at which the current traces in the upper part were taken. 


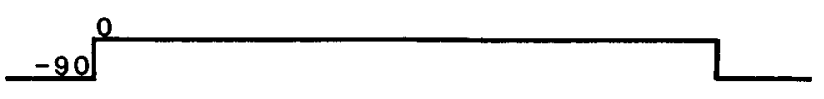

UNTREATED

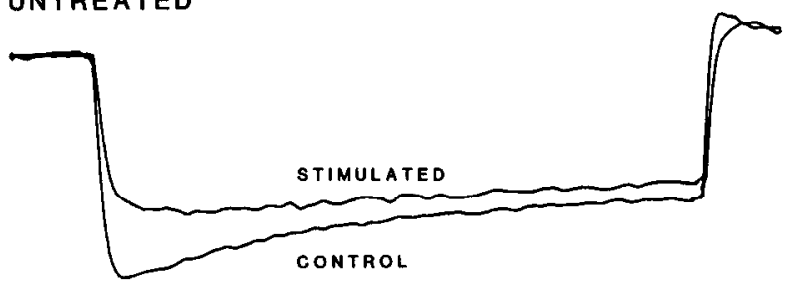

DOMPERIDONE, $1 \mu \mathrm{M}$

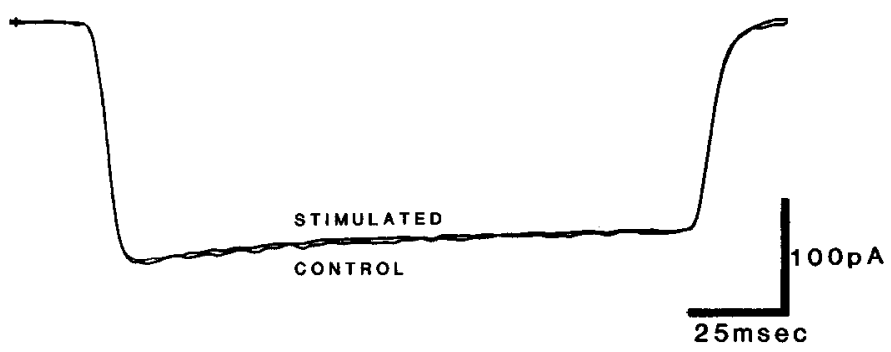

Figure 6. Domperidone, a D-2 receptor antagonist, blocks synaptic inhibition of $\mathrm{Ca}^{2+}$ currents. Current traces were taken from cells held at $-90 \mathrm{mV}$ and stepped up to $0 \mathrm{mV}$. Control and Stimulated refer to traces taken immediately before and $5 \mathrm{sec}$ after stimulation of the pituitary stalk. Before addition of domperidone, stalk stimulation clearly reduced $\mathrm{Ca}^{2+}$ currents (upper). Following addition of the antagonist (lower), this effect was abolished.

$\mathrm{mV}$ were reduced to $62 \pm 12 \%$ (mean $\pm \mathrm{SD}, n=8$ ) of control values, while currents elicited by pulses from -30 to $0 \mathrm{mV}$ were $96 \pm 6 \%$ of control (Fig. 2). The inhibition of the $\mathrm{Ca}^{2+}$ currents was reversible (Fig. 3) and relatively consistent from cell to cell. Examination of the waveforms of the currents after stalk stimulation suggested that the noninactivating current persisted while the transient current was inhibited. This pattern of inhibition of the $\mathrm{Ca}^{2+}$ current was consistent with the preferential inhibition of the $\mathrm{N}$ and $\mathrm{T} \mathrm{Ca}^{2+}$ currents with an apparent sparing of the $\mathrm{L}$ type current.
In our previous paper (Williams et al., 1990), we had described how prepulses to positive potentials appeared to inhibit the $\mathrm{N}$ type $\mathrm{Ca}^{2+}$ current. We therefore compared the effects of stalk stimulation and a $200 \mathrm{msec}$ prepulse to a potential of $+10 \mathrm{mV}$ on the cell's response. As seen in Figure 4, both the prepulse and stalk stimulation produce a similar inhibition of the peak current, providing further evidence that stalk stimulation is selectively abolishing transient $\mathrm{Ca}^{2+}$ currents. The duration of the inhibition of the peak $\mathrm{Ca}^{2+}$ currents by stimulation of the pituitary stalk (Fig. 5) was similar to the previously observed duration of $\mathrm{Ca}^{2+}$ spike inhibition (Fig. 1).

As the presence of bicuculline in the perfusate would block the inhibitory actions of GABA at the GABA $\mathrm{A}_{\mathrm{A}}$ receptor on these cells (Williams et al., 1989b), DA is the probable transmitter mediating these inhibitory responses to stalk stimulation (Williams et al., 1989a). We therefore examined the potential role of DA in the inhibition of $\mathrm{Ca}^{2+}$ currents by perfusing the D-2 antagonist, domperidone ( $1 \mu \mathrm{M} ; n=3$ ) over the preparation. Domperidone totally blocked the inhibitory effects of stalk stimulation on the $\mathrm{Ca}^{++}$currents (Figs. 6, 7) without having any effect on leak current. We next determined if the inhibition of $\mathrm{Ca}^{2+}$ currents elicited by stalk stimulation could be mimicked by quinpirole $(5 \mu \mathrm{M})$, an agonist at the D-2 receptor. Quinpirole mimicked the action of pituitary stalk stimulation by inhibiting $\mathrm{Ca}^{2+}$ currents evoked from a holding potential of $-90 \mathrm{mV}$, but not $-30 \mathrm{mV}$ (Fig. $8 ; n=5$ ).

Some of dopamine's actions on hormone release from the melanotroph have been shown to be mediated by G-proteins (Cote et al., 1985). Therefore, experiments were carried out to assess the role of $\mathrm{G}$-proteins in the inhibition caused by synaptically released DA or exogenously applied DA agonists. In rats pretreated with pertussis toxin, which inactivates some G-proteins, only 3 of 12 cells showed any inhibition of $\mathrm{Ca}^{2+}$ currents due to stalk stimulation. This is significantly different ( $p<0.05 ; \chi^{2}$ test) than the $100 \%$ of cells $(n=30)$ which normally display inhibition of $\mathrm{Ca}^{2+}$ currents duc to stalk stimulation. Quinpirole was also without effect on $\mathrm{Ca}^{2+}$ currents in melanotrophs taken from pertussis toxin-treated rats ( $n=3$; Fig. 9).

In a second series of experiments, melanotrophs were impaled with electrodes containing GTP $\gamma \mathrm{S}(50 \mu \mathrm{M})$, a GTP analog which
Figure 7. Domperidone, a D-2 antagonist, blocks the inhibitory effects of stalk stimulation on $\mathrm{Ca}^{2+}$ currents. Current voltage traces from a cell at a holding potential of $-90 \mathrm{mV}$ and stepped in $10 \mathrm{mV}$ increments to membrane potentials indicated by the data points. Control peak $\mathrm{Ca}^{2+}$ currents were obtained (open triangles) after which $\mathrm{Ca}^{2+}$ currents were again elicited following stalk stimulation in the absence of (closed circles) and the presence of the D-2 antagonist domperidone $(1 \mu \mathrm{M}$ open circles).

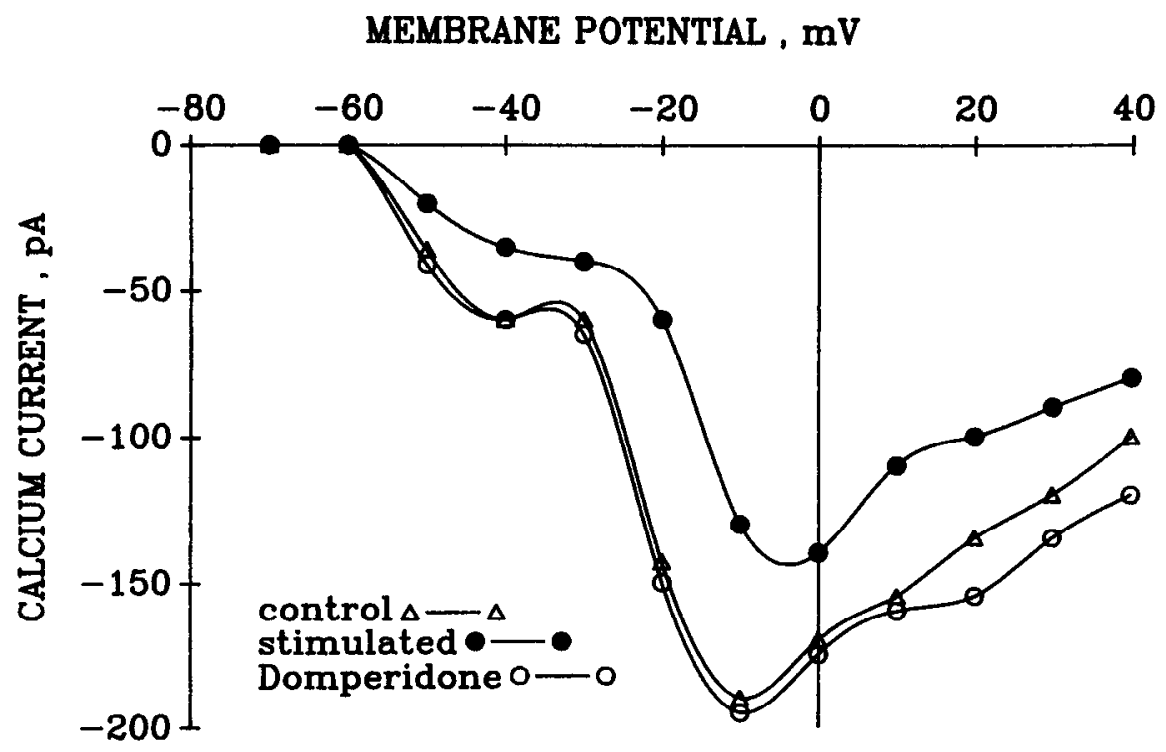


A

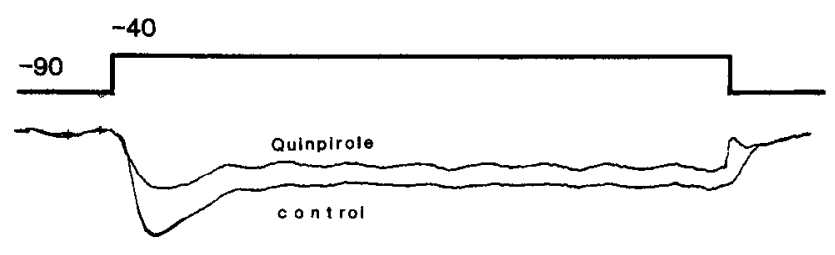

B

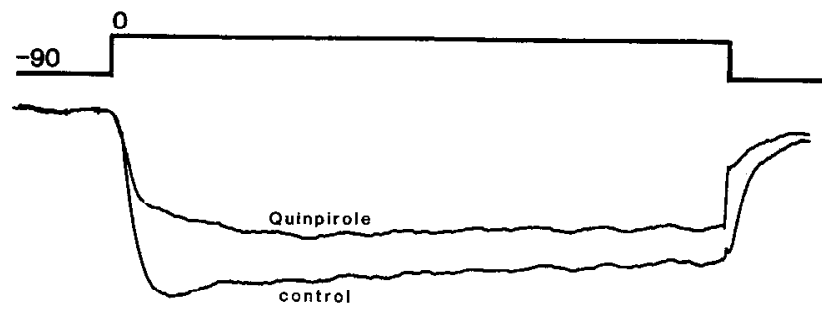

C

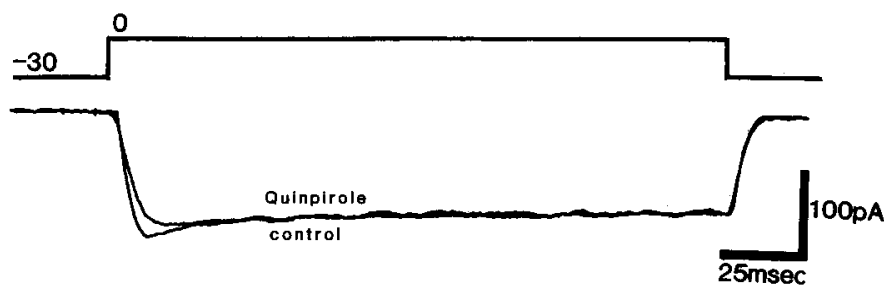

Figure 8. Quinpirole, a D-2 agonist, inhibits inactivating, but not noninactivating, inward $\mathrm{Ca}^{2+}$ currents. From holding potentials indicated to the left of each voltage trace, the voltage was stepped up to the values indicated above each voltage trace. Addition of quinpirole $(5 \mu \mathrm{M})$ in hibited both the low- $(A)$ and the high-threshold $(B) \mathrm{Ca}^{2+}$ currents but did not appreciably inhibit the noninactivating current $(C)$ elicited from a holding potential of $-30 \mathrm{mV}$. irreversibly activates G-proteins. In all cells recorded with GTP $\gamma \mathrm{S}$ in the electrode $(n=15), \mathrm{Ca}^{2+}$ current amplitude was lower than in cells recorded without GTP $\gamma \mathrm{S}$, and neither stalk stimulation nor quinpirole caused a further reduction in current amplitude. Inspection of current records revealed no inactivating $\mathrm{Ca}^{2+}$ current, suggesting that the $\mathrm{T}$ - and $\mathrm{N}$-type currents were abolishcd. To confirm this, voltage pulses were applied from a holding potential of $-90 \mathrm{mV}$, which would activate $\mathrm{T}, \mathrm{N}$, and $\mathrm{L}$ types, or from a holding potential of $-30 \mathrm{mV}$, which would activate only $L$ type. In control cells, a significant difference was seen in response to these 2 protocols (Williams et al., 1990), reflecting inactivation of $\mathrm{N}$-type current at the $-30 \mathrm{mV}$ holding potential. In cclls impaled with electrodes containing GTP $\gamma \mathrm{S}$, however, the response from $-90 \mathrm{mV}$ was virtually the same as the response from $-30 \mathrm{mV}$ (Fig. 10), suggesting that the $\mathrm{N}$ type current was abolished in these cells. Comparison of individual current responses to a $200 \mathrm{msec}$ test pulse from -90 to $0 \mathrm{mV}$ also suggests that the initial rapidly inactivating current is abolished in GTP $\gamma$ S-treated cells.

\section{Discussion}

$\mathrm{Ca}^{2+}$ currents similar to the $\mathrm{T}, \mathrm{N}$, and $\mathrm{L}$ subtypes have been identified in pituitary melanotrophs (Taleb et al., 1986; Williams et al., 1990). As we described in our previous paper (Williams et al., 1990), there are reports of $\mathrm{Ca}^{2+}$ currents that do not fall readily into the classification scheme proposed by Nowycky et al. (1985); however, we believe that the currents we describe here are sufficiently similar that the $\mathrm{T}, \mathrm{N}$, and $\mathrm{L}$ designations are appropriate and uscful. In the present study, we have shown that both synaptically released DA and an exogenously applied $D-2$ agonist reduce inactivating ( $\mathrm{T}$ and $\mathrm{N}$ ) $\mathrm{Ca}^{2+}$ currents while leaving the noninactivating $(\mathrm{L})$ type unaffected. Our conclusions are based both on the fact that currents activated from a holding potential of $-30 \mathrm{mV}$ are unaffected by stalk stimulation or D-2 agonists and from an examination of the waveforms of the $\mathrm{Ca}^{2+}$ currents before and after dopaminergic activation. In both cases, noninactivating currents ( $L$ type) persist and inactivating ( $T$ and $\mathrm{N})$ are reduced. As we have previously demonstrated that DA

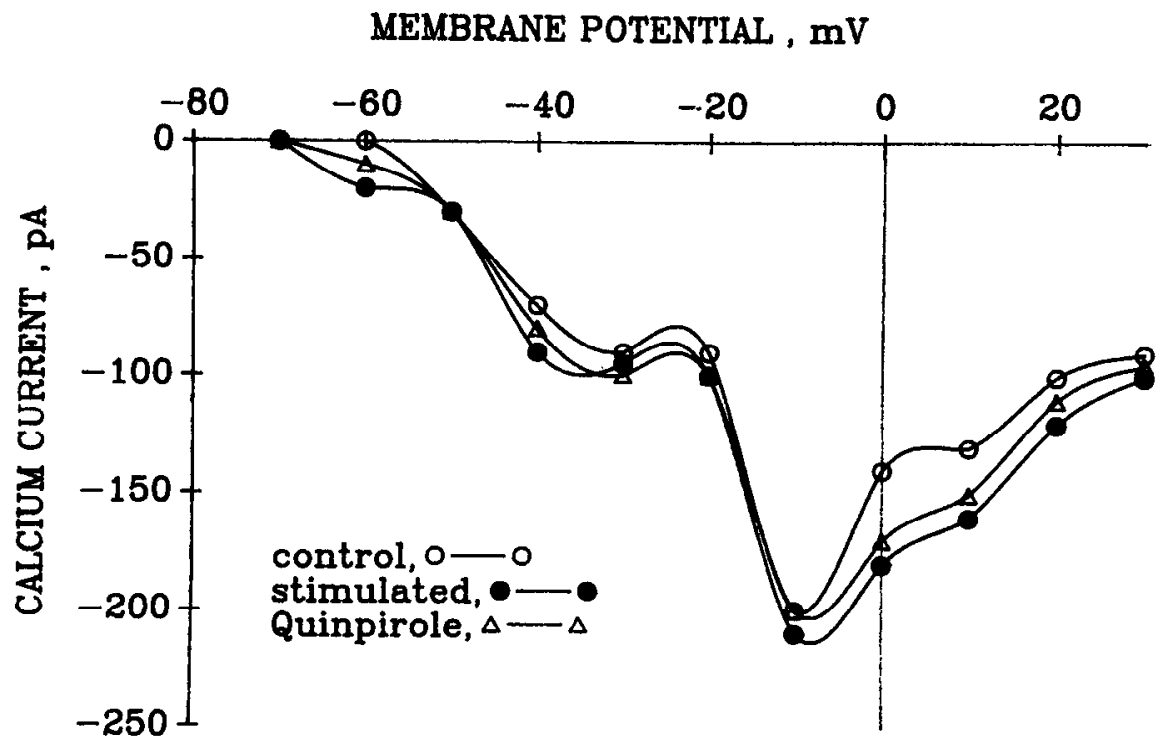

Figure 9. Pertussis toxin pretreatment blocks dopamine-mediated inhibition of $\mathrm{Ca}^{2+}$ currents. Current voltage plots show peak $\mathrm{Ca}^{2+}$ currents obtained in response to $200 \mathrm{msec}$ test pulses to levels indicated by the data points from a holding potential of $-90 \mathrm{mV}$. Open circles are control responses, closed circles are responses following stalk stimulation, and open triangles are $\mathrm{Ca}^{2+}$ currents in the presence of quinpirole. It can be seen that stalk stimulation and quinpirole were without effect on the $\mathrm{Ca}^{2+}$ currents in these cells. 
Figure 10. GTP $\gamma \mathrm{S}$ inhibits T- and $\mathrm{N}$-type $\mathrm{Ca}^{2+}$ currents. Currents recorded in response to voltage pulses from a holding potential of -90 or $-30 \mathrm{mV}$ to test voltages between -70 and +40 $\mathrm{mV}$. Plot shows essentially similar current response from the 2 different holding potentials. Inset, Leak-subtracted currents from a control cell and from a cell impaled with an electrode containing GTP $\gamma$ S. Currents are in response to $200 \mathrm{msec}$ voltage pulse from -90 to 0 $\mathrm{mV}$.
MEMBRANE POTENTIAL , $\mathrm{mV}$

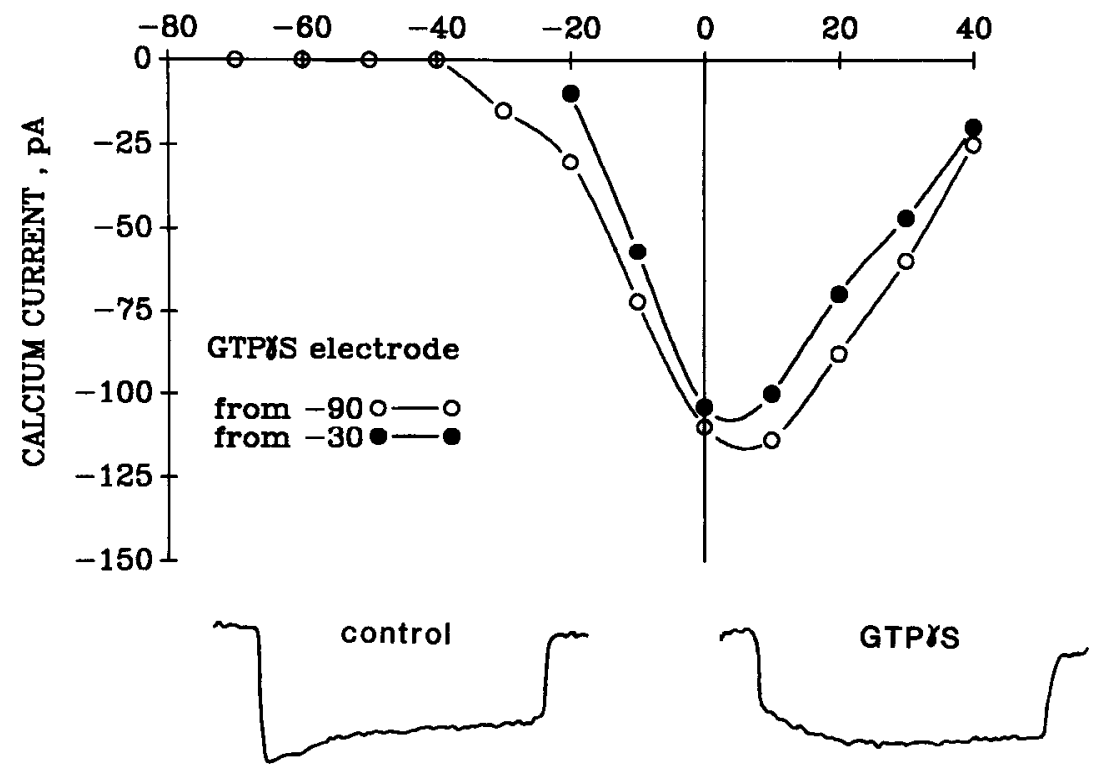

activates a $\mathrm{K}^{+}$conductance in these cells (Williams et al., 1989a), it is important to determine that the effect on $\mathrm{Ca}^{2+}$ currents is not secondary to a change in $\mathrm{K}^{+}$conductance. In our experiments, in order to isolate the $\mathrm{Ca}^{2+}$ current, it was necessary to utilize a number of $\mathrm{K}^{+}$channel blockers; we have previously shown that a combination of intracellular injection of $\mathrm{Cs}^{+}$and TEA plus extracellular 4-AP blocks all voltage-activated $\mathrm{K}^{+}$ conductances (Williams et al., 1990). We also have observed previously (Williams et al., 1989a) that the DA IPSP due to an increased $\mathrm{K}^{+}$conductance was blocked when intracellular electrodes contained $\mathrm{Cs}^{+}$and TEA. Also, no change in the holding currents due to activation of an outward current was seen in the present experiments following stalk stimulation. Finally, it would appear unlikely that a shunting of the membrane due to a DA-activated $\mathrm{K}^{+}$conductance, if present, would affect only the $\mathrm{T}$ and $\mathrm{N}$ currents while leaving the $\mathrm{L}$ current intact.

Our demonstration that DA agonist application reduces $\mathrm{Ca}^{2+}$ spikes is consistent with the previous observations of Douglas and Taraskevich (1978) that DA slows action potential frequency in pars intermedia cells. In a subsequent study of the effects of DA on $\mathrm{Ca}^{2+}$ spikes in these cells (Douglas and Taraskevich, 1982), DA was shown to inhibit $\mathrm{Ca}^{2+}$ spikes, but this effect was seen in only 3 of 11 cells whereas in our experiments stalk stimulation or DA agonist application was always found to inhibit $\mathrm{Ca}^{2+}$ currents. The reasons for this discrepancy are possibly related to the high $(10 \mathrm{~mm})$ levels of $\mathrm{Ca}^{2+}$ uscd in the previous study or to the possible metabolism or oxidation of DA before it reached its site of action.

Our observation of the dopaminergic reduction of $\mathrm{Ca}^{2+}$ currents is in keeping with many recent observations on transmitter modulation of $\mathrm{Ca}^{2+}$ currents (see Dunlap and Fischbach, 1981; Miller, 1987; Tsien et al., 1988). In particular, they add to the growing evidence that DA depresses $\mathrm{Ca}^{2}$ currents in a variety of cells (Lewis et al., 1984; Paupardin-Tritsch et al., 1985; Israel et al., 1987; Malgaroli et al., 1987; Harris-Warrick et al., 1988). To the best of our knowledge, this is the first demonstration of synaptic modulation by DA of a $\mathrm{Ca}^{2+}$ current in the mammalian nervous system. Evidence for this is based on 2 observations:
(1) the similarity between the action of the D-2 agonist quinpirole and that of synaptic stimulation on the $\mathrm{Ca}^{2+}$ current and (2) the ability of a specific D-2 antagonist domperidone (Baudry et al., 1979; Laduron and Leysen, 1979; Lazareno and Nahorski, 1982) to block the inhibitory effect of stalk stimulation on $\mathrm{Ca}^{2+}$ currents.

There is now considerable evidence that certain voltage-dependent $\mathrm{Ca}^{2+}$ channels are controlled by G-proteins (Holtz et al., 1986; reviewed in Rosenthal et al., 1988). Indeed, in Helix neurons there is evidence that an $\alpha_{40}$ subunit of a GTP-binding protein immunologically related to $G_{0}$ mediates a DA-induced decrease in $\mathrm{Ca}^{2+}$ currents (Harris-Warrick et al., 1988). The inhibition of $\mathrm{Ca}^{2+}$ currents in the melanotroph also appears to be G-protein mediated since (1) pertussis toxin, which catalyzes the ADP-ribosylation of $G_{I}$ and $G_{0}$, thus rendering them inactive, blocks the effects of DA and (2) the effects of DA are mimicked by GTP $\gamma$ S, which irreversibly activates G-proteins.

It is interesting that we have previously observed that the DA-induced activation of a $\mathrm{K}^{+}$current in the melanotroph is also mediated by G-proteins (Williams et al., 1989a). There is also evidence that DA receptor activation reduces adenylate cyclase activity in these cells (reviewed in Cote et al., 1985) and that this event is also G-protein mediated (Cote et al., 1984). The interrelationship between these different systems remains to be elucidated.

Our rcsults underline the utility of melanotroph as an ideal preparation for investigation of the electrophysiological and biochemical consequences of D-2 receptor activation. In particular, the compact nature of the cell circumvents difficulties which have arisen in other systems (see Lewis et al., 1984), wherein it has been difficult to examine DA-induced currents because their dendritic locus resulted in potential space-clamp problems. In addition, the lack of interneurons and complicated circuitry in the intermediate lobe greatly simplifies the interpretation of synaptically mediated events. The melanotroph, therefore, represents a powerful model system for the study of dopaminergic neurotransmission and the neuronal control of hormone release. 


\section{References}

Aghajanian, G. K., and Y. Y. Wang (1986) Pertussis toxin blocks the outward currents evoked by opiate and $\alpha_{2}$ agonists in locus coeruleus neurons. Brain Res. 371: 390-394.

Baudry, M., M. P. Martres, and J. C. Schwartz (1979) ${ }^{3}$ H-domperidone: A selective ligand for dopamine receptors. Arch. Pharmacol. 308: 231-237.

Baumgarten, H. G., A. Bjorklund, A. F. Holstein, and A. Nobin (1972) Organization and ultrastructural identification of catecholamine nerve terminals in the neural lobe and pars intermedia of the rat pituitary. Z. Zellforsch. 126: 483-517.

Colmers, W. F., and Q. J. Pittman (1989) Presynaptic inhibition by neuropeptide $\mathrm{Y}$ and baclofen in hippocampus: Insensitivity to pertussis toxin treatment. Brain Res. 498: 99-104.

Cote, T. E., E. A. Frey, and R. D. Sekura (1984) Altered activity of the inhibitory guanyl nucleotide-binding component $\left(\mathrm{N}_{\mathrm{i}}\right)$ induced by pertussis toxin. J. Biol. Chem. 259: 8693-8698.

Cote, T. E., E. A. Frey, R. D. Sekura, and J. W. Kebabian (1985) Dual regulation of adenylate cyclase activity and hormone release in the intermediate lobe of the rat pituitary gland: Evidence for the involvement of membrane components of the stimulatory $\beta_{2}$-adrenergic system and of the inhibitory D-2 dopaminergic system. Adv. Cyclic Nucleotide Res. 19: 151-167.

Douglas, W. W., and P. S. Taraskevich (1978) Action potentials in gland cells of rat pituitary pars intermedia: inhibition by dopamine, an inhibitor of MSH secretion. J. Physiol. (Lond.) 285: 171-184.

Douglas, W. W., and P. S. Taraskevich (1980) Calcium component to action potentials in rat pars intermedia cells. J. Physiol. (Lond.) 309: 623-630.

Douglas, W. W., and P. S. Taraskevich (1982) Slowing effects of dopamine and calcium-channel blockers on frequency of sodium spikes in rat pars intermedia cells. J. Physiol. (Lond.) 326: 201-211.

Dunlap, K., and G. D. Fischbach (1981) Neurotransmitters decrease the calcium conductance activated by depolarization of embryonic chick sensory neurones. J. Physiol. (Lond.) 317: 519-535.

Goldman, M. E., M. Beaulieu, J. W. Kebabian, and R. L. Eskay (1983) $\alpha$-Melanocyte stimulating hormone-like peptides in the intermediate lobe of the rat pituitary gland: Characterization of content and release in vitro. Endocrinology 112: 435-441.

Harris-Warrick, R. M., C. Hammond, D. Paupardin-Tritsch, V. Homburger, B. Rouot, J. Bockaert, and H. M. Gerschenfeld (1988) An $\alpha_{40}$ subunit of a GTP-binding protein immunologically related to $G_{0}$ mediates a dopamine-induced decrease of $\mathrm{Ca}^{2+}$ current in snail neurons. Neuron 1: 27-32.

Holtz, G. G. IV, S. G. Rane, and K. Dunlap (1986) GTP-binding proteins mediate transmitter inhibition of voltage-dependent calcium channels. Nature 319: 670-672.

Howe, A. (1973) The mammalian pars intermedia: A review of its structure and function. J. Endocrinol. 59: 385-409.

Israel, J. M., C. Kirk, and J. D. Vincent (1987) Electrophysiological responses to dopaminc of rat hypophysial cclls in lactotroph-cnriched primary cultures. J. Physiol. (Lond.) 390: 1-22.

Laduron, P. M., and J. E. Leysen (1979) Domperidone, a specific in vitro dopamine antagonist, devoid of in vivo central dopaminergic activity. Biochem. Pharmacol. 28: 2161-2165.

Lazareno, S., and S. R. Nahorski (1982) Selective labelling of dopamine $\left(\mathrm{D}_{2}\right)$ receptors in rat striatum by $\left[{ }^{3} \mathrm{H}\right]$ domperidone but not by [ $\left.{ }^{3} \mathrm{H}\right]$ Spiperone. Eur. J. Pharmacol. 81: 273-285.

Lewis, D. V., G. B. Evans, and W. A. Wilson (1984) Dopamine reduces slow outward current and calcium influx in burst-firing neuron R15 of Aplysia. J. Neurosci. 4: 3014-3020.

MacVicar, B. A., and Q. J. Pittman (1986) Novel synaptic responses mediated by dopamine and $\gamma$-aminobutyric acid in neuroendocrine cells of the intermediate pituitary. Neurosci. Lett. 64: 35-40.

Malgaroli, A., L. Vallar, F. R. Elahi, T. Pozzan, A. Spada, and J. Meldolesi (1987) Dopamine inhibits cytosolic $\mathrm{Ca}^{2+}$ increases in rat lactotroph cells: Evidence of a dual mechanism of action. J. Biol. Chem. 262: 13920-13927.

McCleskey, E. W., A. P. Fox, D. Feldman, and R. W. Tsien (1986) Different types of calcium channels. J. Exp. Biol. 124: 177-190.

Miller, R. I. (1987) Multiple calcium channels and neuronal function. Science 238: 46-52.

Nowycky, M. C., A. P. Fox, and R. W. Tsien (1985) Three types of neuronal calcium channel with different calcium agonist sensitivity. Nature 316: 440-443.

Paupardin-Tritsch, D., L. Colombaioni, P. Deterre, and H. M. Gerschenfeld (1985) Two different mechanisms of calcium spike modulation by dopamine. J. Neurosci. 5: 2522-2532.

Pittman, Q. J., J. Disturnal, C. Riphagen, W. L. Veale, and L. Bauce (1985) Perfusion techniques for neural tissue. In Neuromethods, Vol. 1: General Neurochemical Techniques, A. A. Boulton and G. B. Baker, eds., pp. 279-303, Humana Press, Inc.,

Rosenthal, W., J. Hescheler, W. Trautwein, and G. Schultz (1988) Control of voltage-dependent $\mathrm{Ca}^{2+}$ channels by $\mathrm{G}$ protein-coupled receptors. FASEB J. 2: 2784-2790.

Taleb, O., J. Trouslard, B. A. Demeneix, and P. Fletz (1986) Characterization of calcium and sodium currents in porcine pars intermedia cells. Neurosci. Lett. 66: 55-60.

Taraskevich, P. S., S. A. Tomiko, and W. W. Douglas (1986) Electrical stimulation of neurointermediate lobes of mice elicits calcium-dependent output of melanocyte-stimulating hormone. Brain Res. 379. 390-393.

Tilders, F. J. H., A. H. Mulder, and P. G. Smelik (1975) On the presence of a MSH-release inhibiting system in the rat neurointermediate lobe. Neuroendocrinology 19: 125-130.

Tsien, R. W., D. Lipscombe, D. V. Madison, K. R. Bley, and A. P. Fox (1988) Multiple types of neuronal calcium channels and their selective modulation. Trends Neurosci. 11: 431-438.

Williams, P. J., B. A. MacVicar, and Q. J. Pittman (1989a) A dopaminergic IPSP mediated by an increased potassium conductance. Neuroscience 31: 673-681.

Williams, P. J., B. A. MacVicar, and Q. J. Pittman (1989b) Identification of a GABA-activated chloride mediated synaptic potential in rat pars intermedia. Brain Res. 483: 130-134.

Williams, P. J., B. A. MacVicar, and Q. J. Pittman (1990) Electrophysiological properties of neuroendocrine cells of the intact rat pars intermedia: Multiple calcium currents. J. Neurosci. 10: 748-756. 